\title{
A dermatomyositis and scleroderma overlap syndrome with a remarkable high titer of anti-exosome antibodies
}

\section{Sindrome da sovrapposizione di dermatomiosite e sclerodermia con anticorpi anti-esosoma ad alto titolo}

\author{
R. Gutiérrez-Ramos, V. González-Díaz, M.G. Pacheco-Tovar, A. López-Luna, \\ E. Avalos-Díaz, R. Herrera-Esparza \\ Department of Immunology, Centro de Biología Experimental, Universidad Autónoma de Zacatecas
}

\begin{abstract}
RIASSUNTO
In questo caso clinico viene descritta una sindrome da sovrapposizione di dermatomiosite e scleroermia. Il caso riguarda un soggetto di sesso femminile di 27 anni con un'evoluzione clinica di 14 mesi caratterizzata da debolezza della muscolatura prossimale, rash eritematoso a polsi, ginocchia, caviglie, papule di Gottron, rash eliotropo periorbitale e disfagia. Una biopsia muscolare si dimostrava compatibile con dermatomiosite; mentre la biopsia cutanea era compatibile con sclerodermia. Gli enzimi muscolari erano aumentati. La determinazione degli autoanticorpi su cellule HEp-2 dimostrava un quadro di tipo nucleolare con titolo di 81.920. Gli anticorpi Anti-Jol erano negativi, mentre risultavano positivi gli anti-PM/Scl-100. La paziente veniva trattata con boli di metilprednisolone e di ciclofosfamide, con progressivo miglioramento. L'elevatissimo titolo di anticorpi antinucleo costituisce la particolarità del caso clinico presentato.
\end{abstract}

Reumatismo, 2008; 60(4):296-300

\section{INTRODUCTION}

n 1972, Sharp et al described the mixed connec-
tive tissue disease; such a description corre-
sponded to an apparently distinct rheumatic dis-
ease syndrome associated to U1RNP, which is an
extractable nuclear antigen or ENA (1).
After this clever description, different overlap syn-
dromes that did not meet the EMTC criteria were
described. Conceptually Alarcón-Segovia coined
the term of "shared autoimmunity", which was de-
fined by the presence of two or more data compat-
ible with autoimmune disease; such category of
disease describes signs or symptoms of certain au-
toimmune connective diseases, for instance Rupus
corresponds to lupus erythematosus associated to

Indirizzo per la corrispondenza:

Dr. Rafael Herrera-Esparza

Chepinque 306

Col. Lomas de la Soledad. Zacatecas

Zac. 98040. México

E-mail: rafael.herreraesparza@gmail.com rheumatoid arthritis without a particular serologic profile, others like the sclerodermatomyositis are associated to specific antibodies such as anti$\mathrm{PM} / \mathrm{Scl}$ antibodies (2), this serologic system was described more than two decades ago, PM/Scl antigen was immunochemically characterized by the serum from a patient with sclerodermatomyositis, that reacted against a moiety present in a calf thymus extract and was named $\mathrm{PM} / \mathrm{Scl}$ antigen.

This moiety is located in the nucleolus of HEp-2 cells (3), the prevalence of anti-PM/Scl in sclerodermatomyositis overlap syndrome is $\sim 24 \%$; however anti-PM/Scl antibody is not exclusive, because it was reported in $8 \%$ of patients with polymyositis and in $3 \%$ of patients with scleroderma $(3,4)$. In summary, overlap syndromes are now clinically and serologically well characterized, and have been included as separate entities in the inflammatory myopathies new classification (5).

We report a clinical case of scleroderma-dermatomyositis overlap syndrome with exceptional high titers of antinuclear antibodies with fine specificity to anti-PM/Scl-100. 


\section{CLINICAL CASE}

A 27-year-old female who works in farming labor, who attended to a public hospital with a clinical picture of 14 months evolution, characterized by fever, generalized fatigue, myalgia and significant weakness, which predominantly affected the proximal muscle groups (e.g., shoulder and limb girdles), she also complained of disease-related functional limitation, polyarthritis of hands, knees, sclerodactyly with complete Raynaud's phenomenon and dysphagia.

During first evaluation rheumatoid arthritis was the probable diagnosis; she received therapy with prednisone $5 \mathrm{mg}$ daily, methotrexate $12.5 \mathrm{mgr}$ weekly and celecoxib $200 \mathrm{mg}$ daily. In spite of this therapy, the disease progression was not modified in the following two months. She was later evaluated in the Department of Immunology with the aforementioned clinical picture. The physical examination showed temperature of $38.9^{\circ} \mathrm{C}$, blood pressure of $100 / 60 \mathrm{mmHg}$, pulse with 120 beats per minute, hyperpigmentation in frontal area and heliotrope periorbital rash.

Thorax with normal lungs auscultation; the abdominal examination showed a positive Castell's sign and discrete enlargement of liver and spleen. Additionally she exhibited the characteristic Gottron sign over methacarpophalangeal joints and an erythematous rash in wrists, knees and ankles. There was muscular swelling, tenderness and weakness of scapular and pelvic muscular groups. Also calcinosis cutis in forearms and legs was detected. From the functional point of view she had inability to walk.

The clinical laboratory tests showed increase of muscle enzymes Lactate dehydrogenase (LDH) 7658 U/l, Phosphocreatine kinase (CPK) 7100 U/1 and Creatine kinase (CK) $890 \mathrm{U} / \mathrm{l}$; the erythrocyte sedimentation rate (Wintrobe) was $52 \mathrm{~mm} / \mathrm{h}$. Additionally she had positive antinuclear antibodies by indirect immunofluorescence on HEp- 2 cells at 1:81,920 titers, with a nucleolar fluorescent pattern. Fine specificity was defined by Western blot using a HEp-2 cell extract and a prototype serum, results of these studies disclosed a $100 \mathrm{kDa}$ immunoreactive band correspondent to $\mathrm{PM} / \mathrm{Scl}-100$; this was assumed because the prototype anti-PM/Scl serum gave similar reactivity. The Jo1 specificity tested by ELISA was negative.

A muscle biopsy from biceps exhibited inflammation of large vessels, fibers with circumscribed areas of myofibrillar loss and perimysial infiltrates.
A Punch skin biopsy (4 $\mathrm{mm}$ in diameter) stained with hematoxylin-eosin and Masson's trichrome showed thickening of median reticular dermis.

In present case, the clinical, laboratory and pathology data were considered to establish the diagnosis of sclerodermatomyositis overlap syndrome; with this notion, she received $1.5 \mathrm{~g}$ of cyclophosphamide and methylprednisolone in monthly pulses in the following six months. She gradually improved and the concentration of muscle enzymes progressively decreased, concurrently the muscle tenderness and weakness diminished; therefore, her functional status became acceptable and she returned to work six months later.

\section{DISCUSSION}

A clinical case of scleroderma and dermatomyositis overlap syndrome is presented. The serologic hallmark is the presence of antinuclear antibodies with nucleolus fluorescent pattern; usually the sera from these patients recognize the protein $\mathrm{PM} / \mathrm{Scl}$, which is a component of the exosome complex. The prevalence of anti-PM/Scl autoantibody is $\sim 24 \%$ of these cases $(5,6)$, however, it could be higher in children affected of scleroderma and related diseases (7).

Polydermatomyositis and scleroderma overlap syndromes are now classified as distinct inflammatory myopathies entities; therefore, the new classification takes into account the serological profiles such as the anti-Syntetase (Jo1), anti-SRP (signal recognition of particle), and anti-nucleoporin, these autoantibodies are markers of chronic myositis; meanwhile, anti-U1RNP, PM/Scl, or anti-Ku are markers of monophasic myositis (6).

The idea that autoimmune connective tissue disease could be overlapped was originally proposed by Sharp et al. (1), they identified a group of patients with symptoms of lupus, scleroderma, dermatomyosytis and rheumatoid arthritis, the novel clinical entity was named Mixed Connective Tissue Disease (MCTD); subsequent studies showed that the $50 \%$ of these cases remain as non-differentiated MCTD for years, and display high anti-U1RNP titers, $30 \%$ of the remaining cases evolve to SLE, and a $20 \%$ evolve to scleroderma. There is an association of the sclerodermatomyositis overlap syndrome to anti-PM/Scl autoantibody and HLA DQA1.0501 allele $(8,9)$.

The antigen $\mathrm{PM} / \mathrm{Scl}$ is part of the exosome, and is composed by various exo-ribonucleolytic enzymes; 

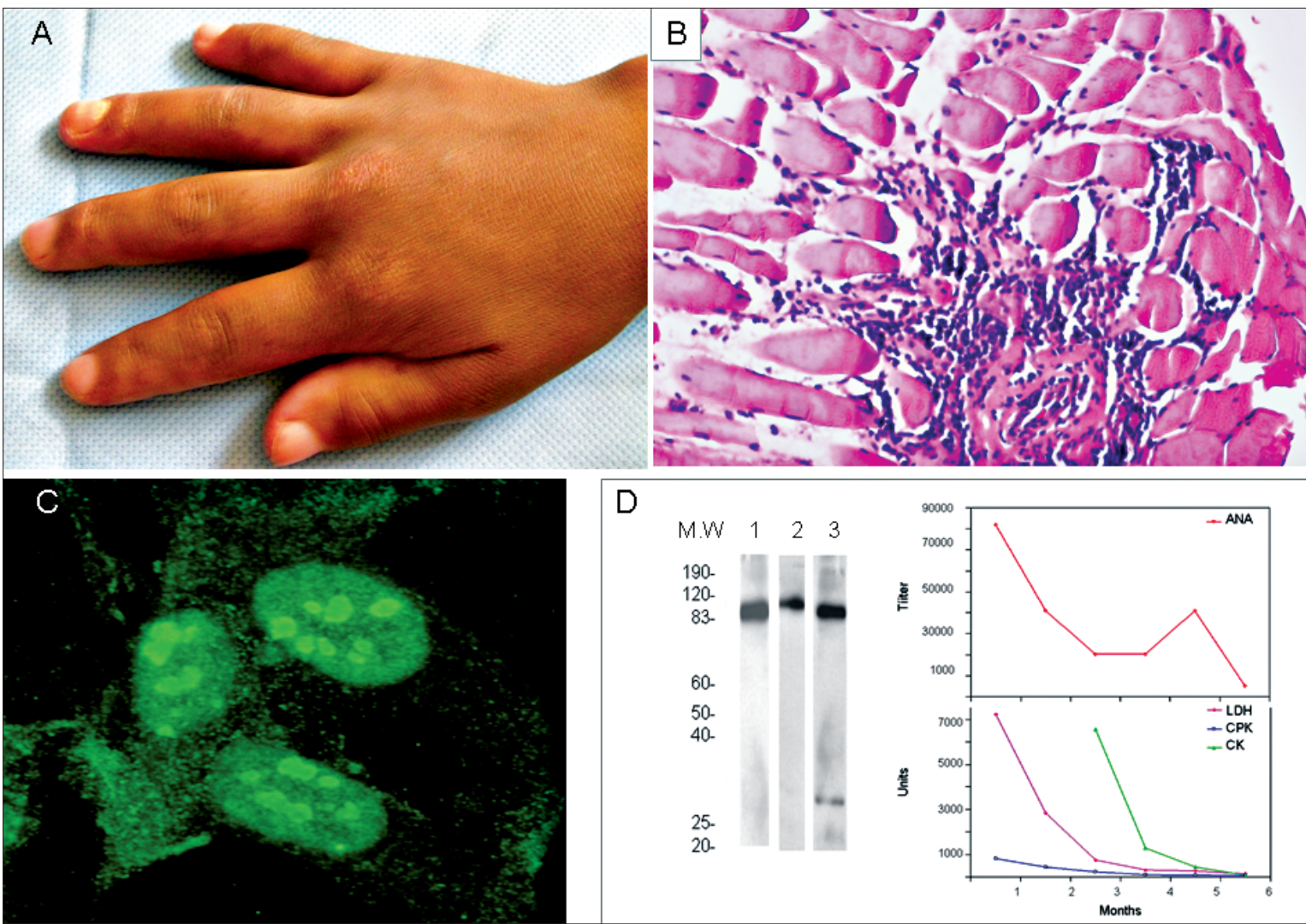

Figura 1 - A sclerodermatomyositis case. A) Sclerodactyly and Gottron rash. B) Muscle biopsy by hematoxilin-eosin stain, showing mononuclear cells infiltrates C) Anti-nucleolar antibodies on HEp-2. D. Western blot of HEp-2 cell extract. Molecular weight standards are on the left. 1) Anti-PM/Scl-100 prototype serum. 2) Patient serum at first evaluation, showing a $100 \mathrm{kDa}$ band corresponding to PM/Scl-100 protein. 3) Patient serum two months later recognizes two bands: the superior is $\mathrm{PM} / \mathrm{Scl}-100$; meanwhile, a small $39 \mathrm{kDa}$ probably corresponds to an aberrant peptide of PM/Scl-75. D) ANA titers (upper part of the graph) and muscle enzymes after a six months follow-up, expressed in International Units. $\mathrm{LDH}=$ Lactate dehydrogenase. $\mathrm{CPK}=$ Creatinfosfokinase. $\mathrm{CK}=$ Creatinkinase.

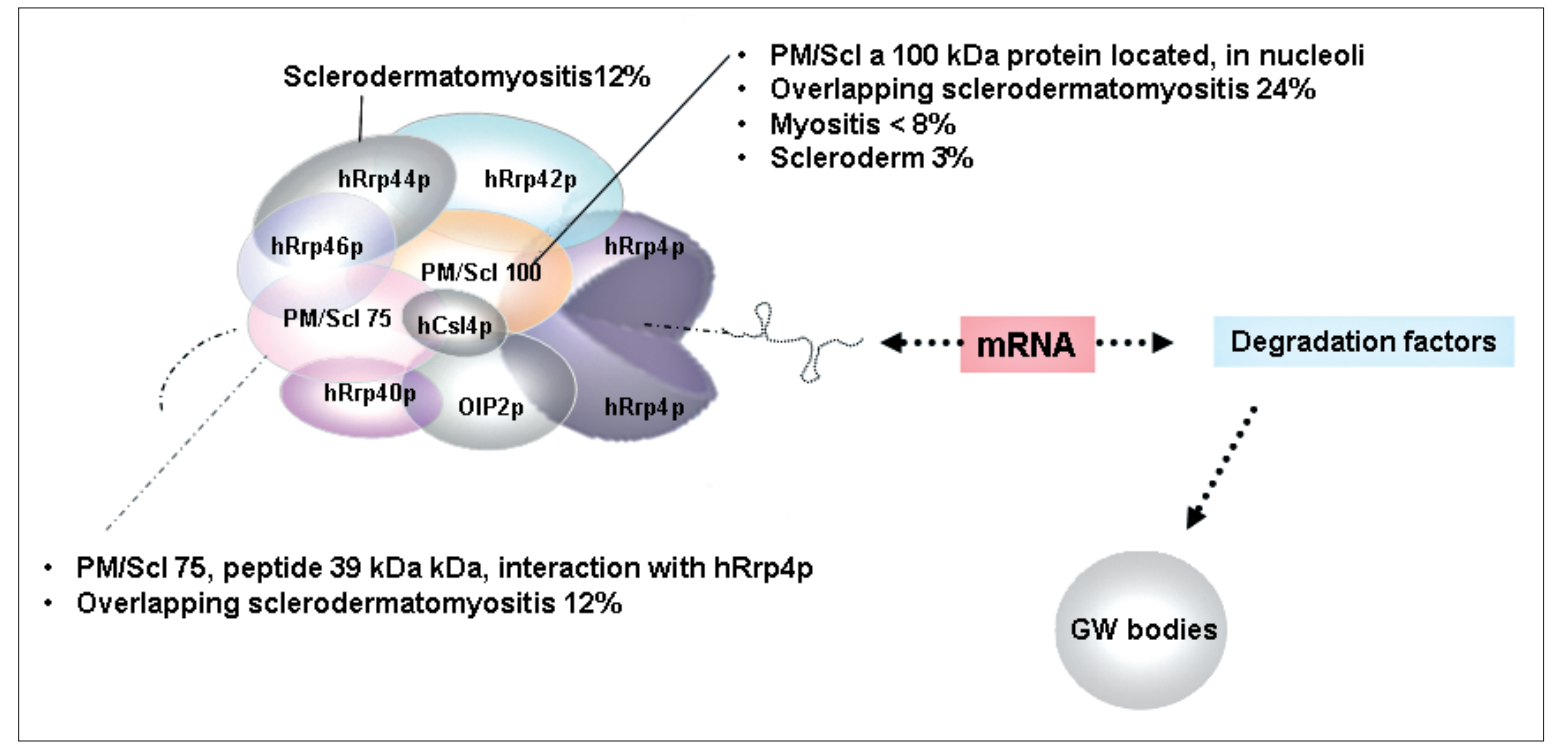

Figura 2 - Exosome and mRNA pathway degradation. Distribution of anti-exosome autoantibodies in autoimmune connective tissue diseases. 
the exosome participates in 3' end mRNA degradation, and it also is an rRNAs and small nucleolar RNAs processing factor, this multienzymatic complex was discovered in yeast (10).

The exosome, in concert with the auxiliary factors, recruits the target mRNA; then develops its exoribonucleolytic activity and produces mRNA degradation (11).

Human exosome includes ten components, among them are $\mathrm{PM} / \mathrm{Scl} 100$ and $\mathrm{PM} / \mathrm{Scl}-75$, both proteins are recognized by sera of sclerodermatomyositis overlap syndrome. These and other exosomic components are 3'/5' exoribonucleases are assembled as an hexameric structure that mimics a donut, and the mRNA target is degraded in the center of the hexamer (11-13).

Autoantibodies against exosome can be detected in $5-8 \%$ of inflammatory myositis, in $3 \%$ of scleroderma and in $24 \%$ in sclerodermatomyositis overlap syndrome (14). Other exosomic components recognized by anti-PM/Scl autoantibodies are hRrp4p, hRrp40p, hRrp41p, hRrp42p, hRrp46p y hCsl4p (15) (Fig. 2).
The present clinical report corresponds to a patient with sclerodermatomyositis overlap syndrome with an exceptional high titer of antinucleolar antibodies. The nucleolar fluorescent pattern of the serum reported here, coincides with the nucleolar location of exosome components; therefore, its molecular reactivity shows a $100 \mathrm{kDa}$ band correspondent to $\mathrm{PM} / \mathrm{Scl}-100$; interestingly a new serum sample taken three months after the first evaluation, exhibited two immunoreactive bands, one of 100 and another of $39 \mathrm{kDa}$, the latter probably corresponded to an aberrant peptide of $\mathrm{PM} / \mathrm{Scl} 75$. This finding probably suggests an epitope spreading phenomenon; this means that the initial response was against $\mathrm{PM} / \mathrm{Scl} 100$ protein and then reactivity spread against an additional moiety (15).

In conclusion, a sclerodermatomyositis patient with a remarkable antinucleolar antibody titer and $\mathrm{PM} / \mathrm{Scl}$ specificity is reported, this is a rare serological case with a monophasic myositis evolution. Finally, it is important to take in consideration the serology in these patients, because autoantibodies can be a sensible monitor of disease behavior.

\section{SUMMARY}

An overlap syndrome of dermatomyositis and scleroderma is reported. The case corresponded to a 27-year-old female with a clinical picture of 14 months evolution, characterized by proximal muscles weakness, erythematous rash in wrists, knees, ankles, Gottron sign, heliotrope periorbital rash and dysphagia. A muscle biopsy was compatible with dermatomyositis; meanwhile the skin biopsy was compatible with scleroderma. Muscle enzymes were increased. Interestingly, the antinuclear antibody determination in HEp-2 cells was positive with a remarkable titer of 81,920 exhibiting a nucleolar pattern. Anti-Jo1 antibody was negative, but anti-PM/Scl-100 positive. The patient received methylprednisolone and cyclophosphamide pulses, with gradual improvement. Present report constitutes a case of overlap dermatomyositis-scleroderma syndrome, with anti-PM/Scl autoantibodies (anti-exosome). The remarkable of this case was the exceptional high antinucleolar antibody titer.

Parole chiave - Sclerodermatomiosite, anticorpi antinucleo, anticorpi anti-PM/Scl, sindrome da sovrapposizione, esosoma.

Key words - Sclerodermatomyositis, antinucleolar antibodies, anti-PM/Scl antibodies, overlap syndrome, exosome.

\section{REFERENCES}

1. Sharp GC, Irvin WS, Tan EM, Gould RG, Holman HR. Mixed connective tissue disease an apparently distinct rheumatic disease syndrome associated with a specific antibody to an extractable nuclear antigen (ENA). Am J Med 1972; 52: 148-59.

2. Rodríguez-Reyna TS, Alarcón-Segovia D. Overlap syndromes in the context of shared autoimmunity. Autoimmunity 2005; 38: 219-23.

3. Reichlin M, Maddison PJ, Targoff I, Bunch T, Arnett F, Sharp G, et al. Antibodies to a nuclear/nucleolar anti- gen in patients with polymyositis overlap syndromes. J Clin Immunol 1984; 4: 40-4.

4. Targoff IN, Reichlin M. Nucleolar localization of the PM-Scl antigen. Arthritis Rheum 1985; 28: 226.

5. Troyanov Y, Targoff IN, Tremblay JL, Goulet JR, Raymond Y, Senécal JL. Novel classification of idiopathic inflammatory myopathies based on overlap syndrome features and autoantibodies: analysis of 100 French Canadian patients. Medicine (Baltimore). 2005; 84: 231-49.

6. Mahler M, Raijmakers R. Novel aspects of autoantibodies to the PM/Scl complex: clinical, genetic and diagnostic insights. Autoimmun Rev 2007; 6: 432-7. 
7. Scalapino K, Arkachaisri T, Lucas M, Fertig N, Helfrich DJ, Londino AV, et al. Childhood onset systemic sclerosis: classification, clinical and serologic features, and survival in comparison with adult onset disease. $\mathrm{J}$ Rheumatol 2006; 33: 1004-13.

8. Jablonska S, Blaszczyk M. Scleroderma overlap syndromes. Adv Exp Med Biol 1999; 455: 85-92.

9. Mahler M, Raijmakers R, Dähnrich C, Blüthner M, Fritzler MJ. Clinical evaluation of autoantibodies to a novel PM/Scl peptide antigen. Arthritis Res Ther 2005; 7: R704-13.

10. Mitchell P, Petfalski E, Shevchenko A, Mann M, Tollervey D. The exosome: A conserved eukaryotic RNA processing complex containing multiple $3^{\prime} \rightarrow 5^{\prime}$ exoribonucleases. Cell 1997; 91: 457-66.

11. Vanacova S, Stefl R. The exosome and RNA quality control in the nucleus. EMBO Rep 2007; 8: 651-7.

12. Van Dijk EL, Schilders G, Pruijn GJ. Human cell growth requires a functional cytoplasmic exosome, which is involved in various mRNA decay pathways. RNA 2007; 13:1027-35.
13. Herrera-Esparza R, Pachecho-Tovar D, Avalos-Díaz E. GW bodies: from RNA biology to clinical implications in autoimmunity. Exp Rev Clin Immunol 2008; 41: 21-5.

14. Brouwer R, Pruijn GJM, van Venrooij WJ. The human exosome: an autoantigenic complex of exoribonucleases in myositis and scleroderma. Arthritis Res 2001; 3: 102-6.

15. Brouwer R, Vree Egberts WTM, Hengstman GJD, Raijmakers R, van Engelen BGM, Seelig HP, et al. Autoantibodies directed to novel components of the $\mathrm{PM} / \mathrm{Scl}$ complex, the human exosome. Arthritis Res 2002; 4: 134-8.

14. Brouwer R, Pruijn GJM, van Venrooij WJ. The human exosome: an autoantigenic complex of exoribonucleases in myositis and scleroderma. Arthritis Res 2001; 3: $102-6$.

15. Brouwer R, Vree Egberts WTM, Hengstman GJD, Raijmakers R, van Engelen BGM, Seelig HP, et al. Autoantibodies directed to novel components of the $\mathrm{PM} / \mathrm{Scl}$ complex, the human exosome. Arthritis Res 2002; 4: 134-8. 